\title{
Oligofructose and experimental model of neonatal necrotising enterocolitis
}

\author{
M.-J. Butel ${ }^{1}$, A.-J. Waligora-Dupriet ${ }^{1}$ and O. Szylit ${ }^{2}$ \\ ${ }^{1}$ UFR des Sciences Pharmaceutiques et Biologiques, Laboratoire de Microbiologie, 4 avenue de l'Observatoire, Université \\ René Descartes, F-75270 Paris Cedex 06, France \\ ${ }^{2}$ Unité d'Ecologie et Physiologie du Système Digestif, Equipe Métabolites Bactériens et Santé, Institut National de la \\ Recherche Agronomique, Jouy-en Josas, France
}

\begin{abstract}
The gut of preterm neonates is colonised with a paucity of bacterial species originating more from the environment than from the mother. Furthermore, a delayed colonisation by bifidobacteria promotes colonisation by potentially pathogenic bacteria. This may contribute towards the development of neonatal necrotising enterocolitis (NEC). The physiopathology of NEC is still unclear but immaturity of the gut, enteral feeding and bacterial colonisation are all thought to be involved. None of the current preventive treatments are considered satisfactory. Modulating the autochthonous microflora by probiotics or prebiotics could be a more reliable approach to prevention. Using gnotobiotic quails as an experimental model of NEC we have shown that onset of intestinal lesions requires a combination of low endogenous lactase activity, lactose in diet, and colonisation by lactose-fermenting bacteria such as the clostridia. The protective role of bifidobacteria was demonstrated in this model through a decrease in clostridial populations and in butyric acid. Oligofructose dietary supplementation was shown to enhance this effect with an increase in the bifidobacterial level and consequently a greater decrease in clostridia. However, oligofructose was unable to promote a bifidobacterial acquisition when the microflora was initially deprived of this group. Nevertheless, oligofructose can act as an anti-infective agent and decrease the occurrence or severity of the lesions depending on the bacteria involved. According to these results and to the fact that oligosaccharides are a major component of breast milk, the addition of oligofructose in formula milks may be a nutritional approach to favouring colonisation by a beneficial flora.
\end{abstract}

\section{Premature infants: Necrotising enterocolitis: Oligosaccharides: Gut flora}

\section{Introduction}

In recent years, research on infant nutrition has focused on a number of micro-components present in human milk and which appeared to have major physiological functions (Hilbrands \& Streekstra, 1996). Among these, free oligosaccharides, the third largest solute in human milk, up to $18.5 \mathrm{~g} / 1$ (Brand Miller et al. 1994), are considered to have functions ranging from modulation of morphogenesis and cell adhesion to anti-infective properties and promotion of beneficial gut bacteria (Kuntz \& Rudloff, 1993). Their chemical structures suggest that they are unlikely to be hydrolysed by intestinal enzymes and may represent the 'dietary fibre' content of human milk (Brand Miller et al. 1994).
Oligofructose has been used as a bifidogenic prebiotic in order to prevent digestive disorders in adults and has been demonstrated as capable of specifically stimulating populations of bifidobacteria, and to lower Clostridium sp. and Escherichia coli, in vitro (Wang \& Gibson, 1993), in humans (Gibson et al. 1995) and animal models (Campbell et al. 1997). Furthermore, there is some evidence that free oligosaccharides are potent inhibitors of bacterial adhesion, an initial stage of infection, by acting as cell receptor analogues (Kuntz \& Rudloff, 1993; Newburg, 1997).

Taking this into account, we have focused on the effects of oligofructose on neonatal necrotising enterocolitis (NEC), a gastrointestinal disease in premature infants. These effects were investigated through the changes in the incidence of intestinal lesions, the microflora balance

Abbreviations: NEC, necrotising enterocolitis; SCFA, short-chain fatty acid.

Note: For the definition of the terms inulin and oligofructose please refer to the introductory paper (p. S139) and its footnote.

* Corresponding author: Dr M-J. Butel, tel + 33 (0) 1537399 11, fax + 330 (1) 537399 23, email mjbutel@pharmacie.univ-paris5.fr 
and the production of bacterial metabolites in an experimental model: the gnotobiotic quails associated with faecal flora from healthy or sick premature neonates.

\section{Gut colonisation in premature neonates and the risk of necrotising enterocolitis}

Despite significant advances in neonatal practice, NEC remains a major cause of gastrointestinal emergency in neonatal intensive care units (NICU) and the first cause of death in extremely premature infants. It is a very severe illness characterised by abdominal distension, gastrointestinal bleeding, mucosal ulcerations and intestinal pneumatosis (Neu, 1996). The physiopathology is still unclear and several factors including immaturity of the gut, enteral feeding and bacterial colonisation are involved (Neu, 1996). To date, none of the preventive treatments, i.e. antibiotic therapy, prophylactic aspects and parenteral feeding, is considered fully satisfactory. Thus, modulating the autochthonous microflora by probiotics or prebiotics could be a rational approach towards prevention.

Normally, the gastrointestinal tract, sterile during foetal life, is colonised at birth with bacteria acquired from the mother during delivery and/or from the environment, mainly E. coli and streptococci (Ducluzeau, 1990; Langhendries et al. 1998). Many factors affect this colonisation, especially the mode of feeding and gestational age. The gut of premature neonates is immature and colonised with few bacteria (Butel et al. 1999) (Table 1). This colonisation differs from that of full-term neonates because of the frequent use of antibiotics, isolation, an absence of feeding directly from the breast and local ecology in the NICU. Bifidobacterial colonisation, associated with a protection against infant digestive infection, is delayed for several weeks in favour of high levels of enterobacteria and clostridia in premature infants (Gewolb et al. 1999; Sakata et al. 1985). It has been postulated that this unbalanced intestinal microflora may contribute to a predisposition of NEC (Dai, 1998).

NEC is often associated with enterobacteria such as Klebsiella sp (Westra-Meijer et al. 1983), E. coli (Speer et al. 1976) or several clostridia (Blakey et al. 1985; Cashore et al. 1981; Kliegman et al. 1979; Kosloske, 1994; Loc et al. 1980). Among clostridia, the most commonly isolated species are C. butyricum (Gothefors \& Blenkharn, 1978; Howard et al. 1977; Lawrence et al. 1982; Laverdière et al. 1978) and C. perfringens (Blakey et al. 1985; Kliegman et al. 1979; Kosloske et al. 1978; Kosloske, 1994).
Conversely, no relationship has been found between the acquisition or carriage of toxigenic $C$. difficile and intestinal symptoms (Delmée et al. 1988). Lawrence et al. (1982) postulated that in such infants a non pathogen, with few or no competitors, is able to multiply without interference. Thus bacterial metabolites, over produced in premature infants who are deficient in endogenous lactase, may be absorbed and cause mucosal damage, possibly initiating NEC. The anaerobic intestinal microflora converts carbohydrates to short-chain fatty acids (SCFA). Among them, butyric acid was first related to the cytotoxic factor of $C$. butyricum strains involved in NEC (Popoff et al. 1987). Its over production appear to be a critical factor in regulating the onset of the disease (Bousseboua et al. 1989; Butel et al. 1998b).

\section{An experimental model of necrotising enterocolitis: gnotobiotic quails}

Quails present some interesting similarities with premature infants in terms of gastrointestinal histology and physiology. They are natural alactasic species, their caeca are a pair of blind ending ducts which favour bacterial stasis and the structure of the caecal wall is comparable to that of the intestine with only slight variations (Hodges, 1979). We have developed an experimental model of NEC using gnotobiotic quails, i.e. germ-free quails reared in a sterile isolator, associated with faecal flora specimen belonging to premature infants (Fig. 1). They were fed a lactose diet sterilised by gamma irradiation and containing lactose $6 \%(\mathrm{w} / \mathrm{w})$ to mimic the proportion in human milk (Bousseboua et al. 1989). A combination of low endogenous lactase activity, lactose in diet, intestinal stasis and colonisation by lactose-fermenting bacteria such as $C$. butyricum (Szylit et al. 1997; Bousseboua et al. 1989) or faecal flora specimens from premature infants suffering from NEC (Butel et al. 1998b) have been shown essential to the onset of NEC-like caecal lesions. Gross necrosis was evaluated as follows: normal, thickened, showing pneumatosis and/or having haemorrhagic contents (Fig. 2). Histological findings were also carried out to complete the macroscopic observations (Fig. 3).

\section{Oligofructose participates in the health promoting effects of bifidobacteria}

The health promoting effect of bifidobacteria has been demonstrated in animal models. It appears that bifidobacterial

Table 1. Analysis of gut implantation in twelve premature infants born before 33 weeks of gestation (Butel et al. 1999)

\begin{tabular}{lcll}
\hline & Median level (D21) & \multicolumn{1}{c}{ Range } & \\
\hline Staphylococci & $6 \cdot 10^{6 *}$ & $10^{3}-9 \cdot 10^{9}$ & \\
Enterococci & $10^{8}$ & $4 \cdot 10^{3}-3 \cdot 10^{9}$ & $3 / 12$ non colonised at D26 \\
Enterobacteria & $10^{8}$ & $2 \cdot 10^{3}-3 \cdot 10^{10}$ & delayed colonisation \\
Clostridium & $2 \cdot 10^{6}$ & $10^{4}-2 \cdot 10^{7}$ & $8 / 12$ colonised \\
Bacteroides & & $10^{4}$ and $2 \cdot 10^{7}$ & $2 / 12$ colonised at D15 and D58 \\
Bifidobacteria & & $6 \cdot 10^{4}$ and $4 \cdot 10^{8}$ & $2 / 12$ colonised at D15 and D64 \\
\hline
\end{tabular}

*Bacterial counts expressed as CFU/g of feces. 
$>$ Germ-free quails, with no endogenous intestinal lactase and a physiological intestinal stasis

(caeca)

Associated with either a single bacterial strain or various mixtures of bacteria (Butel et al.

1998)

Fed a diet supplemented with lactose $(6 \%)$

\begin{tabular}{lcc}
\hline Strains & $\begin{array}{c}\text { NEC-like lesions in quails fed a diet } \\
\text { with lactose }\end{array}$ & $\begin{array}{l}\text { without lactose } \\
\text { C. butyricum }\end{array}$ \\
C. perfringens & YES & NO \\
C. paraputrificum & YES & NO \\
C. difficile & NO & NO \\
Klebsiella & NO & NO \\
\hline
\end{tabular}

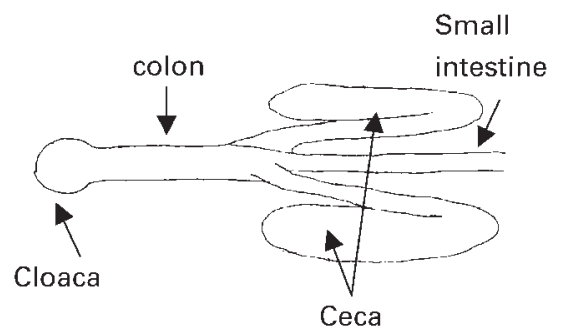

Fig. 1. Experimental model of NEC. Germ-free quails, with no endogenous intestinal lactase and a physiological intestinal stasis (caeca) Associated with either a single bacterial strain or various mixtures of bacteria (Butel et al. 1998a). Fed a diet supplemented with lactose (6\%).

colonisation in the rat model results in a lesser risk for NEC through modulation of the inflammatory cascade (Caplan et al. 1999). In our experimental model fed the lactose diet, bifidobacteria were demonstrated to totally inhibit the development of the caecal lesions (Butel et al. 1998b; Butel \& Szylit, 2000) (Table 2). First, a whole faecal flora including bifidobacteria and no clostridia, isolated from a healthy premature infant, was unable to produce NEC-like caecal lesions. Second, early bifidobacterial supplementation of gnotobiotic quails associated with a NEC-flora resulted in a prevention of cecitis through a modulation of the intestinal microflora. This effect was related to a sharp decrease in clostridial populations and in SCFA concentrations, i.e. butyric acid and SCFA of protein origin.

Oligofructose effects on the intestinal microflora and the incidence of the digestive lesions were investigated in our experimental model in various situations. We compared the

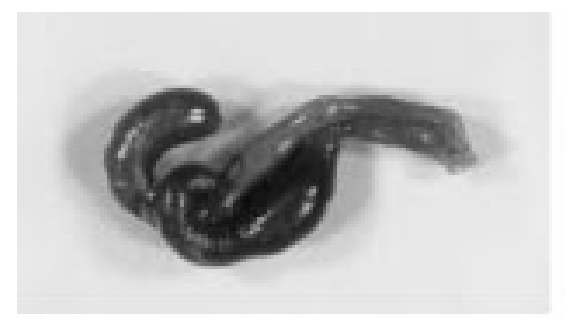

Normal aspect

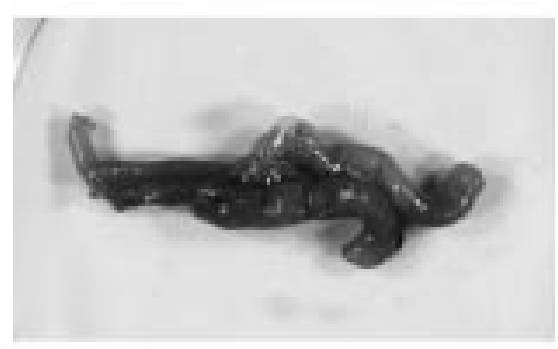

Thickening and first step of pneumatosis

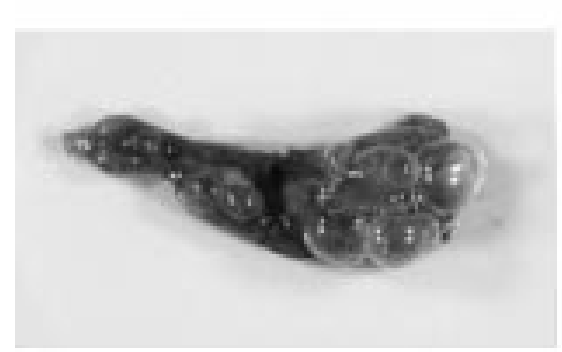

Thickening, pheumatosis and haemorrhagic contents

Fig. 2. Varying macroscopic aspects of the caeca of gnotobiotic quails. 

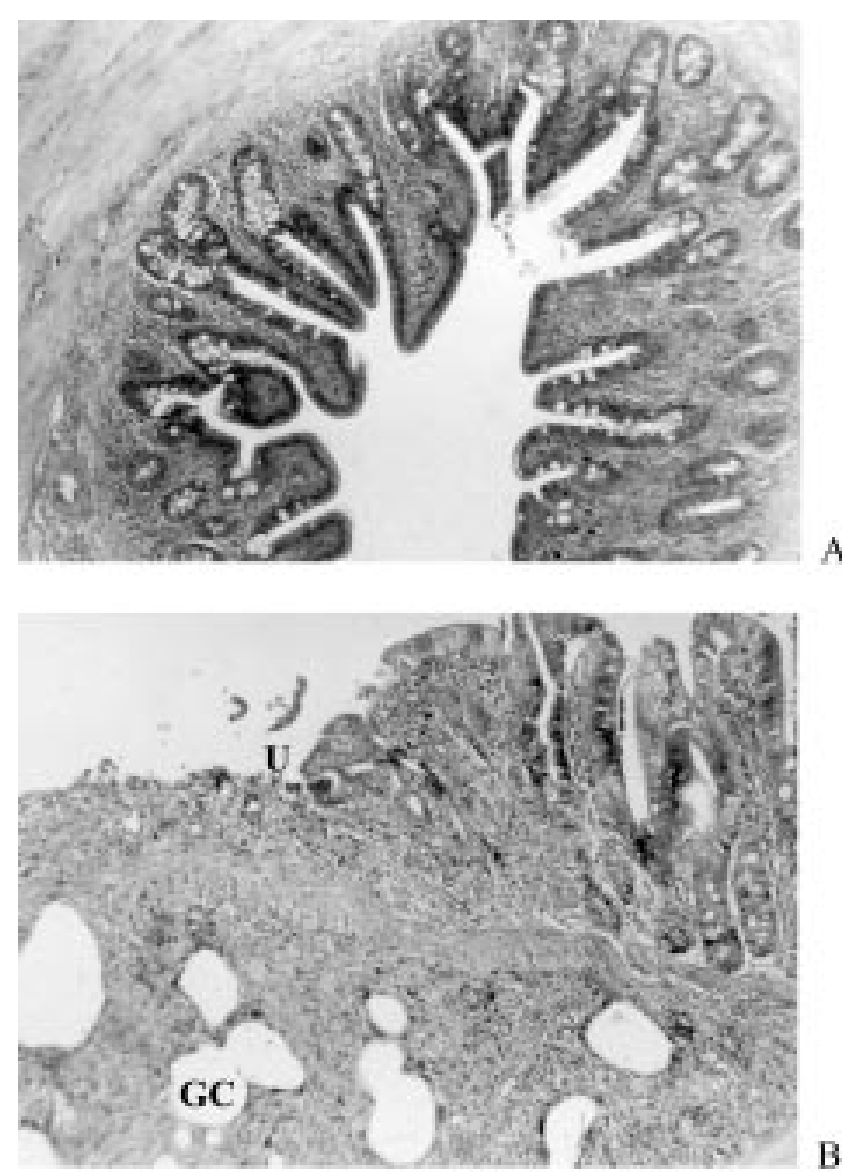

Fig. 3. Varying histological examination of the caeca of gnotobiotic quails (hematoxylin-eosin stain $\times 100$ ) A: Normal pattern; B: Large ulceration of the mucosa (U) and numerous gas cysts (GC).

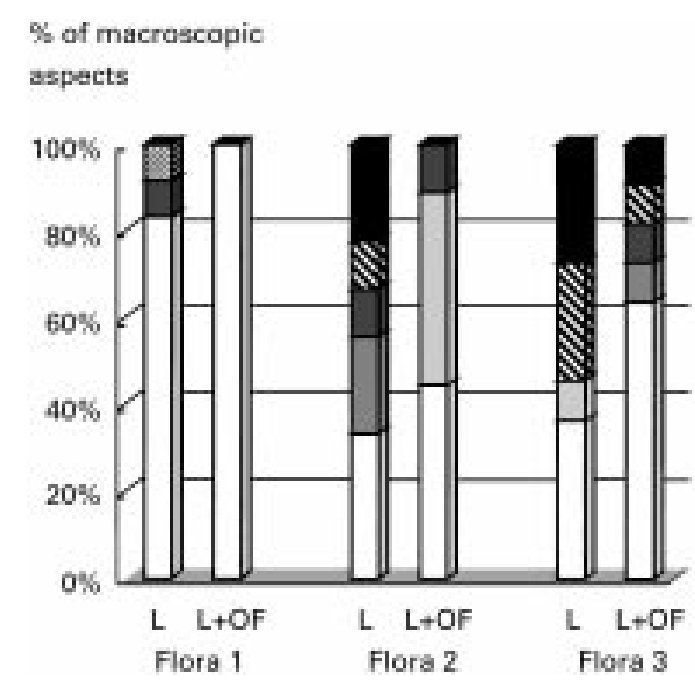

Fig. 4. Influence of oligofructose (OF) on caecal NEC-like lesions in gnotobiotic quails associated with fecal specimens from a healthy (flora 1) and two-NEC suffering (flora 2 and 3) premature infants. $\mathbf{v}=\mathrm{P}+\mathrm{H}+\mathrm{T}, \mathbf{\Delta}=\mathrm{P}+\mathrm{H}, \mathbb{\mathbb { N }}=\mathrm{P}+\mathrm{T}, \boldsymbol{\square}=$ Pneumatosis $(\mathrm{P}), \boldsymbol{\square}=$ Haemorrhagic $(\mathrm{H}), \square=$ Thickening $(\mathrm{T}), \square=$ normal. occurrence of cecitis, bacterial population and metabolism changes between quails fed either the lactose diet $(6 \% \mathrm{w} / \mathrm{w})$ or a lactose-oligofructose diet $(3 \%-3 \% \mathrm{w} / \mathrm{w})$.

Oligofructose is known to stimulate the activity of bifidobacteria in adults and similar results have been observed with gnotobiotic quails fed the oligofructose-supplemented diet (Table 2). This increased bifidobacterial level was associated with a decrease in E. coli and clostridial colonisation depending on the initial composition of the microflora (Catala et al. 1999). Therefore, oligofructose may participate in the health-promoting effect of bifidobacteria by exerting a beneficial effect on microflora balance of the premature infants. The mechanism by which oligofructose plays this role is still under discussion and has often been associated with fermentation of oligofructose by bifidobacteria which subsequently led to a $\mathrm{pH}$ decrease (Wang \& Gibson, 1993; Gibson \& Wang, 1994). In this study the change in $\mathrm{pH}$ and SCFA between the two bifidobacteria groups (fed with or without oligofructose) were minimal.

\section{Protective effect of oligofructose in the absence of bifidobacteria}

Because of the delayed bifidobacterial colonisation in premature neonates, the effect of oligofructose was investigated in absence of bifidobacteria and using clostridial species as a trigger of caecal injury in two specific cases.

In the first study, with gnotobiotic quails kept in the sterilised isolator, health promoting effects of oligofructose against NEC-like lesions caused by a polymicrobial infection were demonstrated, but these effects varied according to clostridial species, implantation level and bacterial association (Table 3). Three groups of germ-free quails were associated with three fecal flora from premature infants, yielding various mixed bacterial species implicated in the onset of NEC and involving C. perfringens known to produce several necrotising extracellular toxins (Finegold, 1977). When fed the lactose diet the occurrence of NEClike lesions varied from $17 \%$ with flora 1 (C. perfringens $<10^{6} \mathrm{CFU} / \mathrm{g}$ caecal content) to $67 \%$ with flora 2 (C. perfringens ca $10^{7} \mathrm{CFU} / \mathrm{g}, C$. difficile) and flora 3 (C. perfringens ca $10^{8} \mathrm{CFU} / \mathrm{g}$, C. difficile, C. paraputrificum), with different states of severity (Figs 3 and 4). Supplementation with oligofructose led to the inhibition of the lesions with flora 1 , and to less extensive tissue necrosis and a sharp decrease in haemorrhages with floras 2 and 3. With flora 3 , the main histological observation was an insignificant and simple caecal inflammation without any severe lesions (Fig. $3 \mathrm{~A}$ ) when quails were fed the lactose+oligofructose diet. Furthermore, the oligofructose beneficial effect was associated with a decrease in bacterial species, i.e. C. perfringens (ca $10^{6} / \mathrm{g}, P<0.05$ ) and $C$. paraputrificum only with flora 3 . Whatever the flora, oligofructose did not alter caecal $\mathrm{pH}$ or short-chain fatty acid concentrations.

\section{Capacity of oligofructose to allow a bifidobacterial colonisation}

The study simulated the conditions in which infants are exposed to various bacteria in neonatal intensive care units. The ability of oligofructose to allow intestinal 
Table 2. Influence of OF on bacterial counts in gnotobiotic quails associated with healthy or NEC-flora

\begin{tabular}{|c|c|c|c|c|c|c|}
\hline \multirow{2}{*}{$\begin{array}{l}\text { Flora } \\
\text { Diet* }^{*}\end{array}$} & \multicolumn{2}{|c|}{ NEC-flora } & \multicolumn{2}{|c|}{ Nec-flora+Bifid } & \multicolumn{2}{|c|}{ Healthy flora } \\
\hline & Lactose & Lac+OF & Lactose & $\mathrm{Lac}+\mathrm{OF}$ & Lactose & $\mathrm{Lac}+\mathrm{OF}$ \\
\hline $\begin{array}{l}\text { Outcome of infection sick quails/total quails } \\
\text { Bacterial counts }\end{array}$ & $6 / 9$ & $5 / 9$ & $0 / 8$ & $0 / 9$ & $0 / 11$ & $0 / 11$ \\
\hline Bifidobacterium & & & $8.6(0.0) \dagger$ & $9 \cdot 2(0 \cdot 1) \ddagger$ & $6 \cdot 9(0 \cdot 2)$ & $7.9(0.3) \ddagger$ \\
\hline C perfringens & $7.2(0.4)$ & $7.5(0 \cdot 3)$ & $3.8(0.3)$ & $<3 \ddagger$ & $\ldots$ & $\cdots$ \\
\hline C difficile & $5.4(0.3)$ & $5.8(0.2)$ & $5.4(0.6)$ & $5.2(0.4)$ & & \\
\hline Enterococci & $9 \cdot 9(0 \cdot 1)$ & $9.5(0.3)$ & $8.6(0.4)$ & $9 \cdot 0(0 \cdot 1)$ & $3.7(0.2)$ & $3.3(0.1)$ \\
\hline Enterobacteria & $8 \cdot 6(0.2)$ & $8 \cdot 0(0.3)$ & $8.1(0.5)$ & $7.1(0.5)$ & $10 \cdot 2(0 \cdot 2)$ & $8.4(0.4)$ \\
\hline
\end{tabular}

Gnotobiotic quails were killed 28 days after inoculation.

* Quails were fed either a lactose $(6 \%)$ or a lactose-OF $(3 \%-3 \%)$ diet.

†Bacterial counts are expressed as mean (SEM) $\log _{10}$ CFU/g wet content, the threshold count was $3 \log _{10} \mathrm{CFU} / \mathrm{g}$

$\ddagger$ Significantly different from control diet within the same bacterial status $(P<0.05)$.

colonisation by exogenous bifidobacteria was determined in gnotobiotic quails associated with a flora deprived of bifidobacteria (Danan et al. 2000) (Table 4). To enable further infection by bacteria from the external environment, air filters were removed from all isolators one week after inoculation. Although quails were housed in an environment containing bifidobacteria, daily oligofructose consumption did not promote intestinal post colonisation by exogenous bifidobacteria in quails initially deprived of this bacterial genus. Nevertheless, the level of C. perfringens decreased (1.6 log lower). These results are in agreement with our previous study that demonstrated the specific inhibition of oligofructose against clostridia in gnotobiotic quails.

If several studies in adults (Garleb et al. 1996; Gibson et al. 1995) and in experimental models (Catala et al. 1999; Howard et al. 1995) showed that the bifidogenic effect of oligofructose is dependent on the initial level of bifidobacteria in the intestinal microflora, the regular ingestion of oligofructose did not entail bifidobacterial colonisation when bifidobacteria were initially absent.

\section{Conclusion}

Comparing the different studies in gnotobiotic quails, the protective effect of oligofructose observed appeared less effective than the probiotic effect of bifidobacteria or the symbiotic effect of oligofructose and bifidobacteria. This led to a complete disappearance of the caecal lesions due to a sharp decrease or the disappearance of clostridial species associated with the disappearance of caecal butyrate concentration. Oligofructose was unable to promote a bifidobacterial acquisition when the microflora was initially deprived of this species. Nevertheless, oligofructose can act as an anti-infective agent and was demonstrated to decrease the occurrence or severity of the intestinal lesions depending on the bacteria involved in the onset of the lesions.

Addition of free oligosaccharides has never been taken into account in premature formulae despite their high levels in human milk, particularly in milk from mothers delivering premature infants and despite the fact that they have major physiological functions. A supplementation with these prebiotics could offer - even in the absence of bifidobacteria - a new approach to improve pre-term formula milk and permit when bifidobacteria are present to maintain the beneficial flora for a long period. These positive results support the need for further clinical investigations on the role of oligofructose in bacterial colonisation and prevention of NEC.

Table 3. Influence of OF on caecal bacterial status of gnotobiotic quails associated with fecal specimens from a healthy (group 1) ot two NEC-suffering (groups 2 and 3) pre-term infants

\begin{tabular}{|c|c|c|c|c|c|c|}
\hline \multirow{2}{*}{$\begin{array}{l}\text { Group } \\
\text { Diet* }^{*}\end{array}$} & \multicolumn{2}{|c|}{ Flora 1} & \multicolumn{2}{|c|}{ Flora 2} & \multicolumn{2}{|c|}{ Flora 3} \\
\hline & Lactose & $\mathrm{Lac}+\mathrm{OF}$ & Lactose & $\mathrm{Lac}+\mathrm{OF}$ & Lactose & $\mathrm{Lac}+\mathrm{OF}$ \\
\hline $\begin{array}{l}\text { Outcome of infection sick quails/total quails } \\
\text { Bacterial counts }\end{array}$ & $2 / 12$ & $0 / 11$ & $6 / 9$ & $5 / 9$ & $7 / 11$ & $4 / 14$ \\
\hline C perfringens & $5.1(0.7) \dagger$ & $6.0(0.5)$ & $7.2(0.4)$ & $7.5(0.3)$ & $7.9(0.2)$ & $6.4(0.1) \ddagger$ \\
\hline C paraputrificum & $\ldots$ & $\ldots$ & & & $8.4(0.1)$ & $5.8(0.3) \ddagger$ \\
\hline C difficile & & & $5.4(0.3)$ & $5.8(0.2)$ & $5.6(0.4)$ & $5.1(0.3)$ \\
\hline K pneumoniae & $7.8(0.6)$ & $8.1(0.4)$ & & & $\ldots$ & $\ldots$ \\
\hline Proteus mirabilis & & & $8.6(0.2)$ & $8.0(0.3)$ & & \\
\hline Enterococci & $9.3(0.3)$ & $8.5(0.4)$ & $9.9(0.1)$ & $9.5(0.3)$ & $8.4(0.2)$ & $9.0(0.2)$ \\
\hline
\end{tabular}

Gnotobiotic quails were killed 28 days after inoculation.

${ }^{*}$ Quails were fed either a lactose $(6 \%)$ or a lactose-OF $(3 \%-3 \%)$ diet.

† Bacterial counts were expressed as mean (SEM) $\log _{10}$ CFU/g wet content, the threshold count was 3 log 10 CFU/g; $n=7$ or eight analyses per group and diet.

$\ddagger$ Significantly different from control diet within the same bacterial status $(P<0.05)$. 
Table 4. Cecal bacterial status in gnotobiotic quails in an ordinary environment and associated with a flora deprived of bifidobacteria

\begin{tabular}{|c|c|c|}
\hline \multirow[b]{2}{*}{ Bacteria } & \multicolumn{2}{|c|}{ Diet } \\
\hline & Lactose & Lactose+OF \\
\hline C difficile & $4.5 \pm 0.5$ * $(5) \dagger$ & $5 \cdot 2 \pm 2.0$ \\
\hline C perfringens & $6.5 \pm 0.9(5)$ & $4.9 \pm 1.3(4) \ddagger$ \\
\hline C malenominatum & $5.7 \pm 1.3(4)$ & $5.1 \pm 1 \cdot 1(2)$ \\
\hline Bacteroides & $<3$ & $<3$ \\
\hline Bifidobacterium & $<3$ & $<3$ \\
\hline Enterobacteria & $<3$ & $<3$ \\
\hline Enterococci & $9.0 \pm 1.0(5)$ & $8.0 \pm 1.4(4)$ \\
\hline
\end{tabular}

Quails were housed in an environment containing bifidobacteria.

*Bacterial counts \pm SD.

† Number of quails colonized.

$\ddagger$ Significantly different from the lactose diet.

\section{Acknowledgements}

This work was supported by ORAFTI, Tienen, Belgique. We thank Dr H. Taper for histological examinations and Pr A-M. Marty for revising the English text.

\section{References}

Blakey JL, Lubitz L, Campbell NT, Gillam GL, Bishop RF \& Barnes GL (1985) Enteric colonization in sporadic neonatal necrotizing enterocolitis. Journal of Pediatric Gastroenterology and Nutrition 4, 591-595.

Bousseboua H, Le Coz Y, Dabard J, Szylit O, Raibaud P, Popoff MR \& Ravisse P (1989) Experimental cecitis in gnotobiotic quails monoassociated with Clostridium butyricum strains isolated from patients with neonatal necrotizing enterocolitis and from healthy newborns. Infection and Immunity 57, 932-936.

Brand Miller J, Bull S, Miller J \& McVeagh P (1994) The oligosaccharide composition of human milk: temporal and individual variations in monosaccharide components. Journal of Pediatric Gastroenterology and Nutrition 19, 371-376.

Butel MJ, Catala I, Tessèdre AC, Bensaada M, Durao J, Szylit O (1998a) Are all bacteria involved in neonatal necrotising enterocolitis responsible for? Proceedings of the 2nd World Congress on Anaerobic Bacteria and Infections, Nice, France 3-6 October 1998.

Butel MJ, Roland N, Hibert A, Popot F, Favre A, Tessèdre AC, Bensaada M, Rimbault A \& Szylit O (1998b) Clostridial pathogenicity in experimental necrotising enterocolitis in gnotobiotic quails and protective role of bifidobacteria. Journal of Medical Microbiology 47, 391-399.

Butel MJ \& Szylit O (2000) Bifidobacteria in necrotizing enterocolitis. Gastroenterology 118, 1280-1281.

Butel MJ, Trombert S, Philippe JC, Hoarau C, Vodovar M, Saliba E, Magny JF \& Borderon JC (1999) Implantation de la flore digestive chez le prématuré., 5 ème journées Francophones de Recherche en Néonatologie, Rouen, 16-18 December 1999.

Campbell JM, Fahey GC \& Wolf BW (1997) Selected indigestible oligosaccharides affect large bowel mass, cecal and fecal short-chain fatty acids, $\mathrm{pH}$ and microflora in rats. Journal of Nutrition 127, 130-136.

Caplan MS, Miller-Catchpole R, Kaup S, Russell T, Lickerman M, Amer M, Xiao Y \& Thomson R (1999) Bifidobacterial supplementation reduces the incidence of necrotizing enterocolitis in a neonatal rat model. Gastroenterology 117, 577-583.

Cashore WJ, Peter G, Lauermann M, Stonestreet BS \& Oh W (1981) Clostridia colonization and clostridia toxin in neonatal necrotizing enterocolitis. Journal of Pediatrics 98, 308-311.
Catala I, Butel MJ, Bensaada M, Popot F, Tessèdre AC, Rimbault A \& Szylit O (1999) Oligofructose contributes to the protective role of bifidobacteria in experimental necrotising enterocolitis in quails. Journal of Medical Microbiology 48, 89-94.

Dai D \& Walker WA (1998) Role of bacterial colonization in neonatal necrotizing enterocolitis and its prevention. Acta Padiatric Sinica 6, 357-365.

Danan C, Huret Y, Bensaada M, Szylit O \& Butel MJ (2000) Could oligosaccharides supplementation promote gut colonization with a beneficial flora in pre-term infant? Journal of Pediatric Gastroenterology and Nutrition 30, 217-219.

Delmée M, Verellen G, Avesani V \& Francois G (1988) Clostridium difficile in neonates: serogrouping and epidemiology. European Journal of Pediatrics 147, 36-40.

Ducluzeau R (1990) L'etablissement de la flore du tractus gastrointestinal chez le nouveau-né humain. Recherche en Gynécologie 2, 71-75.

Finegold S (1977) Anaerobic Bacteria in Human Disease. New York, NY: Academic Press.

Garleb KA, Snook JT, Marcon MJ, Wolf BW \& Johnson WA (1996) Effect of fructo-oligosaccharide containing enteral formulas on subjective tolerance factors, serum chemistry profiles, and faecal bifidobacteria in healthy adult male subjects. Microbial Ecology in Health and Disease 9, 279-285.

Gewolb IH, Schwalbe RS, Taciak VL, Harrison TS \& Panigrahi P (1999) Stool microflora in extremely low birthweight infants. Arch.Dis.Child Fetal Neonatal Ed. 80, F167-F173.

Gibson GR, Beatty ER, Wang X \& Cummings JH (1995) Selective stimulation of bifidobacteria in the human colon by oligofructose and inulin. Gastroenterology 108, 975-982.

Gibson GR \& Wang X (1994) Enrichment of bifidobacteria from human gut contents by oligofructose using continuous culture. FEMS Microbiology Letters 118, 121-128.

Gothefors L \& Blenkharn I (1978) Clostridium butyricum and necrotizing enterocolitis. Lancet $52-53$.

Hilbrands W \& Streekstra H (1996) New Biotechnological Ingredients for Infant Nutrition. pp. 38-40. Maarsen, The Netherlands: Miller Freeman Plc.

Hodges RD (1979) The digestive system. In Histology of the Fowl, pp. 80-84 [RD Hodges, editor]. London: Academic Press.

Howard FM, Bradley JM, Flynn DM, Noone P \& Szawatkowski M (1977) Outbreak of necrotizing enterocolitis caused by Clostridium butyricum. Lancet 1099-1102.

Howard MD, Gordon DT, Pace LW, Garleb KA \& Kerley MS (1995) Effects of dietary supplementation with fructooligosaccharides on colonic microbiota populations and epithelial cell proliferation in neonatal pigs. Journal of Pediatric Gastroenterology and Nutrition 21, 297-303.

Kliegman RM, Fanaroff AA, Izant R \& Speck WT (1979) Clostridia as pathogens in neonatal necrotizing enterocolitis. Journal of Pediatrics 95, 287-289.

Kosloske AM (1994) Epidemiology of necrotizing enterocolitis. Acta Paediatrica 396, Suppl., $2-7$.

Kosloske AM, Ulrich JA \& Hoffman H (1978) Fulminant necrotising enterocolitis associated with clostridia. Lancet 2, 1014-1016.

Kuntz C \& Rudloff S (1993) Biological functions of oligosaccharides in human milk. Acta Paediatrica 82, 903-912.

Langhendries JP, Paquay T, Hannon M \& Darimont J (1998) Acquisition de la flore intestinale néonatale: rôle sur la morbidité et perspectives thérapeutiques. Arch.Pediatr. 5, 644-653.

Laverdière M, Robert A, Chicoine R, Salet D \& Rosenfeld R (1978) Clostridia in necrotising enterocolitis. Lancet 2, 377.

Lawrence G, Bates J \& Gaul A (1982) Pathogenesis of neonatal necrotising enterocolitis. Lancet 137-139.

Loc C, Larroche JC, Paul G \& Beaudoin M (1980) Infection à Clostridium perfringens et entérocolite ulcéro-nécrosante. Archives Françaises de Pédiatrie 37, 233-240. 
Neu J (1996) Necrotizing enterocolitis. The search for a unifying pathogenic theory leading to prevention. Pediatric Clinics of North America 43, 409-432.

Newburg DS (1997) Do the binding properties of oligosaccharides in milk protect human infants from gastrointestinal bacteria? Journal of Nutrition 127, 980S-984S.

Popoff MR, Jolivet-reynaud C \& Carlier JP (1987) Cytotoxic activity of Clostridium butyricum supernatants induced by butyrate. FEMS Microbiology Letters 43, 95-100.

Sakata H, Yoshioka H \& Fujita K (1985) Development of the intestinal flora in very low birth weight infants compared to normal full-term newborns. European Journal of Pediatrics 144, 186-190.
Speer ME, Taber LH, Yow MD, Rudolph AJ, Urteaga J \& Waller S (1976) Fulminant neonatal sepsis and necrotizing enterocolitis associated with a 'nonenteropathogenic' strain of Escherichia coli. The Journal of Pediatrics 89, 91-95.

Szylit O, Butel MJ \& Rimbault A (1997) An experimental model of necrotising enterocolitis. Lancet 350, 33-34.

Wang X \& Gibson GR (1993) Effects of the in vitro fermentation of oligofructose and inulin by bacteria growing in the human large intestine. Journal of Applied Bacteriology 75, 373-380.

Westra-Meijer CMM, Degener JE, Dzoljic-danolovic G, Michel MF \& Mettau JW (1983) Quantitative study of the aerobic and anaerobic faecal flora in neonatal necrotising enterocolitis. Archives of Disease in Childhood 58, 523-528. 